\title{
PERBEDAAN KADAR KOLESTEROL ORANG YANG OBESITAS DENGAN ORANG YANG NON OBESITAS
}

\author{
Yulina Dwi Hastuty* \\ Jurusan Kebidanan Poltekkes \\ Medan, Indonesia \\ *Corresponding Author :yulinadwihastuty@gmail.com
}

\begin{abstract}
Abstrak
Obesitas telah menjadi masalah kesehatan dan gizi masyarakat dunia, baik di negara maju maupun negara berkembang. Prevalensi obesitas meningkat pada beberapa tahun terakhir dan telah menimbulkan masalah kesehatan yang serius. Secara global setidaknya 2,8 juta meninggal setiap tahun terkait dengan peningkatan berat badan dan obesitas. Obesitas yang menetap dan asupan makanan yang berlebih dapat menyebabkan terjadinya gangguan sistem metabolik berupa hiperkolesterolemia. Kondisi berlebihnya kadar kolesterol dalam darah dapat menyebabkan aterosklerosis, penyakit jantung koroner, stroke, dan tekanan darah tinggi yang dapat berujung pada kematian. Obesitas sering dikaitkan dengan kondisi hiperkolesterol, namun adakalanya kadar kolesterol juga tinggi pada orang yang memiliki berat badan normal. Penelitian ini bertujuan untuk mengetahui perbandingan kadar kolesterol pada orang dewasa dengan obesitas dan non obesitas. Jenis penelitian ini adalah deskriptif analitik dengan desain cross sectional. Hipotesa penelitian bahwa kadar kolesterol lebih tinggi pada orang obes dibandingkan non obes. Penelitian ini dilaksanakan di lingkungan Poltekkes Kemenkes Medan. Populasi penelitian ini berjumlah 375 besar sampel ditentukan berdasarkan kriteria inklusi dan pengambilannya secara accidental sampling. Uji data yang digunakan adalah uji $\mathrm{T}$ dengan level signifikan $\mathrm{p}=0.05$. Hasil yang diperoleh dari penelitian ini menunjukkan bahwa tidak ada perbedaan kadar kolesterol antara orang yang obesitas dengan non obesitas dimana rata-rata kadar kolesterol orang yang obesitas adalah 188.89 sedangkan rata-rata kadar kolesterol orang yang non obesitas adalah 190.11. hasil $\mathrm{T}$ test menunjukkan bahwa nilai $\mathrm{t}$ hitung $=0.932$ yang berarti lebih besar dari 0.05 yang artinya kedua kelompok identik (tidak ada perbedaan). Diharapkan bagi pegawai yang ada di poltekkes untuk melakukan aktifitas yang dapat menurunkan kadar kolesterol juga menjaga asupan makanan yang berimbang.
\end{abstract}

Kata Kunci : obes; non obes; kolesterol 


\title{
DIFFERENCES IN BLOOD CHOLESTEROL LEVELS BETWEEN OBESE AND NON OBESE PERSON
}

\begin{abstract}
Obesity has become a public health and nutrition problems of the world, both in developed countries and developing countries. The prevalence of obesity is increasing in recent years and has led to serious health problems. Globally at least 2.8 million deaths each year linked to weight gain and obesity. Obesity persistent and excessive food intake can cause metabolic system disorders such as hypercholesterolemia. Conditions of excess cholesterol in the blood can cause atherosclerosis, coronary heart disease, stroke, and high blood pressure that can lead to death. Obesity is often associated with hypercholesterolemia condition, but sometimes also high cholesterol levels in people who have normal weight. This study aimed to compare the levels of cholesterol in adults with obesity and nonobese.This type of research is descriptive analytic with cross sectional design. Research hypothesis that cholesterol levels were higher in obese than non-obese people. This research was conducted in the Polytechnic Health Ministry of Medan. The study population numbered 375 sample size is determined based on inclusion criteria and uptake by accidental sampling. Test data used is $\mathrm{T}$ test with significant level of $p=0: 05$.The results of this study indicate that there is no difference in cholesterol levels between people who are obese with non-obese where the average cholesterol levels of obese people is 188.89 while the average cholesterol level nonobese person is 190.11. $T$ test results showed that the value of $t=0932$ which means greater than 0.05 which means that the two groups are identical (no difference). Expected for personnel in Poltekkes to perform activities that can lower cholesterol levels also maintain balanced food intake.
\end{abstract}

Keywords: obese;, non obese; cholesterol 


\section{PENDAHULUAN}

Obesitas telah menjadi masalah kesehatan dan gizi masyarakat dunia, baik di negara maju maupun negara berkembang. Prevalensi obesitas meningkat pada beberapa tahun terakhir dan telah menimbulkan masalah kesehatan yang serius. Secara global setidaknya 2,8 juta meninggal setiap tahun terkait dengan peningkatan berat badan dan obesitas dimana 300.000 terjadi di Amerika Serikat dan $\quad 350.000$ di Asia Tenggara ${ }^{\mathbf{1 , 2}}$. Berdasarkan data dari Noncommunicable Disease in South-East Asia Region tahun 2008 prevalensi individu dengan IMT $\geq 25 \mathrm{~kg} / \mathrm{m}^{2}$ mengalami peningkatan di beberapa negara dan di Indonesia persentasinya mencapai $16 \%$ pada laki-laki dan $25 \%$ pada wanita ${ }^{2}$. Data yang diambil dari Riset Kesehatan Dasar (Riskesdas) tahun 2010 melaporkan bahwa $11,65 \%$ orang dewasa berumur $\geq 18$ tahun mengalami obesitas dan angka ini mengalami peningkatan di tahun 2013 yaitu $19,7 \%$ laki-laki berumur $\geq 18$ tahun mengalami obesitas sedangkan pada wanita mencapai angka 32,9 \% 3 . Untuk Sumatera Utara data yang diperoleh dari Riset Kesehatan Daerah (Riskesda) pada tahun 2007 menunjukkan persentase overweight mencapai $11.9 \%$ dan obesitas $13.5 \%$. Tahun 2010 persentase overweight pada laki-laki $10.9 \%$ dan $12.8 \%$ pada wanita, sedangkan persentase obesitas $9.4 \%$ pada laki-laki dan $17.4 \%$ pada wanita ${ }^{4}$.

Meningkatnya jumlah individu dengan obesitas berdampak buruk bagi kesehatan, mengingat obesitas merupakan penyakit kronik yang bersifat poligenik atau monogenik yang dapat mengakibatkan beberapa keadaan disfungsi atau patologis ${ }^{5}$. Beberapa hal yang dapat mempengaruhi obesitas diantaranya faktor genetik, asupan makanan, mekanisme neuroendokrin, sosial budaya dan gaya hidup ${ }^{6}$. Di Indonesia, perubahan gaya hidup yang menjurus ke westernisasi menyebabkan berubahnya pola makan ditambah kurangnya aktifitas fisik dapat menimbulkan dampak terhadap peningkatan resiko obesitas 7,8 .

Obesitas merupakan suatu kondisi ketidakseimbangan antara tinggi badan dan berat badan akibat jumlah jaringan lemak tubuh yang berlebihan, umumnya ditimbun dalam jaringan subkutan, namun karena mengalami gangguan atau kerusakan maka lemak terakumulasi dilapisan viseral ${ }^{9}$. Obesitas terdiri dari 2 macam yaitu obesitas umum dan obesitas sentral/abdominal. Obesitas umum dapat diketahui melalui indikator IMT $\geq 25 \mathrm{~kg} / \mathrm{m}^{2}$ (10) atau $\geq 30$ $\mathrm{kg} / \mathrm{m}^{2}$ (kriteria WHO), sedangkan obesitas sentral/abdominal dapat diketahui melalui indikator rasio lingkar pinggang dan panggul (RLPP). Menurut WHO (2008) batasan RLPP untuk obesitas sentral negara Asia termasuk Indonesia pada laki-laki adalah $>0,90$ dan pada perempuan $>0,85$. Obesitas sentral sangat erat hubungannya dengan terjadinya sindroma metabolik yang salah satu tandanya adalah peningkatan kolesterol darah total .

Kondisi obesitas akan berakibat pada peningkatan resiko hipertensi, diabetes mellitus, penyakit kardiovaskuler, dislipidemia, gagal ginjal dan respon inflamasi11. Komponen dislipidemia termasuk tingginya kadar kolesterol total, trigliserida, LDL dan rendahnya kadar HDL memiliki peran utama dalam peningkatan aterosklerosis dan penyakit kardiovaskular. Kolesterol total termasuk salah satu indikator untuk menentukan risiko penyakit kardiovaskular. Hiperkolesterolemia atau peningkatan kadar kolesterol total umumnya tidak menimbulkan gejala, sehingga pemeriksaan untuk pencegahan dan pemeriksaan rutin kadar kolesterol diperlukan sebagai tindakan pencegahan bagi individu yang beresiko tinggi ${ }^{12}$.

Peningkatan kadar kolesterol yang merupakan resiko terhadap penyakit jantung dan stroke mempunyai perkiraan angka kematian di dunia sekitar 2,6 juta. 
Angka kematian tertinggi sekitar 54\% terjadi di Eropa, kemudian Amerika 48\%. Wilayah Afrika dan Asia Tenggara menunjukkan 22,6\% untuk Afrika dan 29,0\% untuk Asia Tenggara (World Health Organization $(\mathrm{WHO})^{13}$.

Obesitas yang menetap dan asupan makanan yang berlebih dapat menyebabkan terjadinya gangguan sistem metabolik berupa hiperkolesterolemia. Pengaturan metabolisme kolesterol akan berjalan normal apabila jumlah kolesterol dalam darah mencukupi kebutuhan dan tidak melebihi jumlah normal yang dibutuhkan. Namun pada obesitas dinyatakan dapat terjadi gangguan pada regulasi asam lemak yang akan meningkatkan kadar trigliserida dan ester kolesterol. Orang yang mempunyai berat badan lebih seringkali mempunyai kadar kolesterol darah yang lebih tinggi bila dibandingkan dengan orang yang berat badannya normal. Hasil penelitian Shah et al tahun 2008 menunjukkan bahwa pada orang yang obesitas cenderung memiliki kadar kolesterol total yang tinggi.

Peningkatan kolesterol darah juga dapat disebabkan oleh kenaikkan kolesterol yang terdapat pada verylow- density lipoprotein dan low-density lipoprotein sekunder karena peningkatan trigliserida yang besar dalam sirkulasi apabila terjadi penumpukan lemak berlebihan di dalam tubuh ${ }^{12}$.

Kolesterol adalah zat alamiah dengan sifat fisik berupa lemak tetapi memiliki rumus steroida. Kolesterol merupakan bahan pembangun esensial bagi tubuh untuk sintesis zat-zat penting seperti membran sel dan bahan isolasi sekitar serat saraf, begitu pula hormon kelamin, dan anak ginjal, vitamin $\mathrm{D}$, serta asam empedu. Namun, apabila dikonsumsi dalam jumlah berlebih dapat menyebabkan peningkatan kolesterol dalam darah yang disebut hiperkolesterolemia, bahkan dalam jangka waktu yang panjang bisa menyebabkan kematian. Kadar kolesterol darah cenderung meningkat pada orang-orang yang gemuk, kurang berolahraga, dan perokok.

Kondisi hiperkolesterol bisa menyebabkan permasalahan diantaranya aterosklerosis (penyempitan pembuluh darah), penyakit jantung koroner, stroke, dan tekanan darah tinggi. Kadar kolesterol total darah sebaiknya adalah $<200 \mathrm{mg} / \mathrm{dl}$, bila $\geq 200 \mathrm{mg} / \mathrm{dl}$ berarti risiko untuk terjadinya penyakit jantung meningkat. Data Riset Kesehatan Dasar (Riskesdas) tahun 2007 menyebutkan bahwa kelompok usia 45-54 tahun beresiko tinggi terkena penyakit serangan jantung atau stroke 4 .

Hubungan antara obesitas dan tingginya kadar kolesterol darah telah di laporkan baik pada anak maupun dewasa. Gorces C dkk melaporkan bahwa obesitas berhubungan dengan abnormalitas kolesterol dalam darah yaitu meningkatnya kolesterol dalam darah pada usia lebih dari 30 tahun ${ }^{14}$.

\section{METODE PENELITIAN}

Penelitian ini menggunakan desaign penelitian deskriptif analitik dengan pendekatan crossectional. Pengambilan sampel dilakukan dengan teknik accidental sampling yaitu subjek yang datang ke poliklinik dan memenuhi kriteria maka langsung diambil sebagai sampel. Selanjutnya dilakukan pengukuran berat badan, tinggi badan, dan kadar kolesterol total pada subjek penelitian. Berat badan diukur dengan menggunakan timbangan berat badan Digital Personal Scale berkapasitas $150 \mathrm{~kg}$ dengan tingkat ketelitian $0,1 \mathrm{~kg}$. Saat pengukuran alas kaki dan benda yang digenggam subjek penelitian ditanggalkan. Tinggi badan diukur dengan menggunakan microtoise kapasitas panjang $200 \mathrm{~cm}$ dengan tingkat ketelitian $0,1 \mathrm{~cm}$. Pada saat pengukuran alas kaki subjek penelitian ditanggalkan dan berdiri dalam posisi tegak. Setelah 
mendapatkan data tentang berat dan tinggi badan selanjutnya dilakukan perhitungan IMT sesuai dengan rumus perhitungan IMT, kemudian hasilnya dicatat dan dijelaskan kepada subjek penelitian. Kadar kolesterol total diukur dengan alat ukur kolesterol total darah autocheck. Alat dinyalakan dan dimasukkan strip kolesterol. Daerah yang diambil spesimen darah kapiler yaitu pada ujung jari tangan didesinfeksi dengan menggunakan kapas alkohol. Setelah itu, lanset ditusuk ke ujung jari tangan sampai mengeluarkan darah. Darah yang keluar didekatkan ke ujung strip pengukur kadar kolesterol. Hasil pengukuran kadar kolesterol total ditunggu sekitar 3 menit. Apabila hasil pengukuran telah keluar, selanjutnya diberitahu kepada subjek penelitian dan dicatat.

\section{HASIL PENELITIAN}

Jumlah keseluruhan sampel sebanyak 57 orang pegawai yang bekerja di Poltekkes Kemenkes Medan yang diambil secara accidental sampling dan dikategorikan menjadi obesitas dan non obesitas berdasarkan pengukuran indeks massa tubuh (IMT). Data sampel penelitian dilakukan dengan menganalisis data seperti tertulis dibawah ini, kemudian dilakukan pengolahan data statistik dengan menggunakan uji $\mathrm{T}$.

\section{Karakteristik Responden}

Karakteristik responden penelitian dapat dilihat pada tabel dibawah ini:

Tabel 1. Distribusi Frekuensi Responden Berdasarkan Umur Pada Pegawai Poltekkes Kemenkes Medan Tahun 2015

\begin{tabular}{lcc}
\hline Umur (thn) & Frekuensi & $\mathbf{\%}$ \\
\hline $25-34$ & 11 & 19.30 \\
$35-44$ & 20 & 35.08 \\
$45-54$ & 17 & 29.82 \\
$55-64$ & 9 & 15.80 \\
\hline Total & 57 & 100.00 \\
\hline
\end{tabular}

Dari tabel 4.1. dapat diketahui bahwa dari 57 sampel yang telah diteliti, mayoritas berada pada kelompok umur 35 - 44 tahun berjumlah 20 orang (35.08\%).

Tabel 2. Distribusi Frekuensi Responden Berdasarkan Jenis Kelamin Pada Pegawai Poltekkes Kemenkes Medan Tahun 2015

\begin{tabular}{lcc}
\hline Jenis Kelamin & Frekuensi & $\mathbf{\%}$ \\
\hline Perempuan & 41 & 71.93 \\
laki-laki & 16 & 28.07 \\
\hline Total & 57 & 100.00 \\
\hline
\end{tabular}

Dari tabel 4.2. dapat diketahui bahwa dari 57 sampel yang telah diteliti, mayoritas berjenis kelamin perempuan sebanyak 41 orang $(71.93 \%)$.

Tabel 3. Distribusi Frekuensi Responden Berdasarkan IMT Pada Pegawai Poltekkes Kemenkes Medan Tahun 2015

\begin{tabular}{lcc}
\hline \multicolumn{1}{c}{ IMT } & Frekuensi & $\%$ \\
\hline $\begin{array}{l}\text { non obesitas } \\
(<30 \mathrm{~kg} / \mathrm{m} 2)\end{array}$ & 38 & 66.67 \\
$\begin{array}{l}\text { Obesitas }(\geq \\
30 \mathrm{~kg} / \mathrm{m} 2)\end{array}$ & 19 & 33.33 \\
\hline Total & 57 & 100.00 \\
\hline
\end{tabular}

Dari tabel 4.3. dapat diketahui bahwa dari 57 sampel yang telah diteliti berdasarkan IMT, mayoritas sampel pada kategori non obesitas berjumlah 38 orang (66.67\%).

Tabel 4. Distribusi Frekuensi Responden Berdasarkan Kadar Kolesterol Pada Pegawai Poltekkes Kemenkes Medan Tahun 2015

\begin{tabular}{lcc}
\hline \multicolumn{1}{c}{ Kadar Kolesterol } & Frekuensi & $\mathbf{\%}$ \\
\hline$\leq 145 \mathrm{mg} / \mathrm{dl}$ & 11 & 19.30 \\
$>145 \mathrm{mg} / \mathrm{dl}$ & 46 & 80.70 \\
\hline Total & $\mathbf{5 7}$ & $\mathbf{1 0 0 . 0 0}$ \\
\hline
\end{tabular}

Dari tabel 4.4. dapat diketahui bahwa dari 57 sampel yang telah diteliti berdasarkan Kadar Kolesterol, mayoritas memiliki kadar kolesterol $>145 \mathrm{mg} / \mathrm{dl}$ berjumlah 46 orang $(80.70 \%)$. 


\section{Analisa Bivariat}

Tabel 4.5. Perbandingan Kadar Kolesterol Pada Responden obesitas dan non obesitas.

\begin{tabular}{lccccc}
\hline Kategori & \multicolumn{5}{c}{ Kolesterol } \\
\cline { 2 - 6 } & Mean & SD & F & Sig. & $\begin{array}{c}\text { Sig. (2- } \\
\text { tailed) }\end{array}$ \\
\hline $\begin{array}{l}\text { Non } \\
\text { Obesitas }\end{array}$ & 190.11 & 52.734 & .340 & .562 & .932 \\
Obesitas & 188.89 & 44.233 & & & \\
\hline
\end{tabular}

Perbandingan rerata kadar kolesterol antara kelompok obesitas dan non obesitas dapat dilihat pada tabel 4.5. Nilai rerata \pm simpangan baku kadar kolesterol pada kelompok obesitas adalah $44.233 \pm 10.148$ $\mathrm{mg} / \mathrm{dl}$, sedangkan pada kelompok non obesitas adalah $52.743 \pm 8.555 \mathrm{mg} / \mathrm{dl}$. Hal ini menunjukkan rerata kadar kolesterol lebih tinggi pada kelompok non obesitas namun tidak memiliki perbedaan yang signifikan. Dari hasil uji signifikan $t$ test, $t$ hitung diperoleh nilai 0.932 atau $>0.05$ artinya tidak ada perbedaan rata-rata kolesterol antara obesitas dan non obesitas.

\section{PEMBAHASAN}

Berdasarkan karakteristik responden didapati bahwa kategori umur responden terbanyak adalah pada rentang usia 35-44 tahun $(35.08 \%)$, sedangkan jenis kelamin dari responden yang terbanyak adalah perempuan $(71.93 \%)$, untuk kategori IMT persentasi terbesar adalah non obesitas sebanyak $66.67 \%$ dan berdasarkan hasil pemeriksaan kolesterol terbanyak pada kategori > $145 \mathrm{mg} /$ dl. Jika dilihat dari karakteristik responden yang ada dapat dilihat bahwa kadar kolesterol yang didapat dari pegawai yang ada di Poltekkes Kemenkes Medan rata-rata berada pada kategori nilai yang tinggi (> $145 \mathrm{mg} / \mathrm{dl}$ ) hal ini dimungkinkan karena rata-rata responden berkisar pada usia 35-44, menurut penelitian sebelumnya kadar kolesterol cenderung tinggi pada rentang usia diatas 30 tahun $^{14}$ selain itu mayoritas sampel adalah perempuan dimana kadar kolesterol yang tinggi juga lebih banyak dijumpai pada wanita karena terkait hormon estrogen dimana hormon estrogen juga berhubungan dengan pembentukan kolesterol ${ }^{15}$.

Hasil penelitian menunjukkan bahwa rata-rata kadar kolesterol pada kelompok obesitas dan non obesitas tidak memiliki perbedaan yang bermakna karena signifikansinya 0.562 yang berarti $\mathrm{p}>0.05$. setelah dilakukan uji regresi linier didapati nilai $R=0.026$ yang artinya tidak ada hubungan antara kolesterol dengan berat badan. Kolesterol adalah prekursor bagi hormon steroid, asam empedu dan vitamin D. Kolesterol juga merupakan unsur penting dalam membran sel dan lapisan luar lipoprotein ${ }^{16}$.

Hampir seluruh kolesterol dan fosfolipid akan diabsorpsi di saluran gastrointestinal dan masuk ke dalam kilomikron yang dibentuk di dalam mukosa usus. Kolesterol disintesis sepenuhnya dari asetil-KoA di banyak jaringan ${ }^{16}$. Sehingga memungkinkan jika kadar kolesterol bisa tinggi pada setiap individu, tidak terlepas apakah orang tersebut obesitas atau non obesitas. Meskipun beberapa penelitian sebelumnya banyak yang mendapati hasil bahwa kadar kolesterol berhubungan dengan berat badan dan IMT namun sintesis kolesterol juga dipengaruhi banyak faktor. Faktor lain yang dapat mempengaruhi kadar kolesterol plasma selain faktor herediter adalah peningkatan asupan tinggi kolesterol, diet tinggi lemak jenuh, diet tinggi asam lemak tak jenuh dan kekurangan hormon insulin dan tiroid serta kelainan lipoprotein.

Faktor herediter memiliki peranan yang paling besar dalam penentuan kadar kolesterol serum seseorang seperti adanya kelainan mutasi gen pada reseptor LDL menyebabkan pembentukan LDL tinggi. Biasanya ditandai dengan produksi kolesterol $>400 \mathrm{mg} / \mathrm{dL}$ dan kadar kolesterol HDL $<35 \mathrm{mg} / \mathrm{dL}$. Namun, faktor asupan makanan, dan lingkungan seperti aktivitas 
fisik, merokok, juga ikut mempengaruhi kadar kolesterol ${ }^{16}$.

Asupan diet tinggi lemak jenuh turut meningkatkan kadar kolesterol plasma dengan peningkatan sebanyak 15\%-25\%. Hal ini karena terjadi deposit lemak di hati yang kemudian menyebabkan meningkatnya unsur asetil-koA di hati untuk memproduksi kolesterol ${ }^{17}$.

Kekurangan hormon insulin dan tiroid dapat menyebabkan peningkatan kadar kolesterol plasma, sedangkan kelebihan hormon tiroid akan berakibat peningkatan kadar kolesterol plasma. Kemungkinan utama terjadi demikian adalah disebabkan perubahan pada aktivitas enzim yang bekerja pada metabolisme lipid ${ }^{17}$.

Hal lain yang berperan dalam penentuan tinggi atau rendahnya kadar kolesterol adalah olahraga. Olahraga yang sering dikatakan akan menurunkan kadar LDL dalam plasma sedangkan kadar HDL akan meningkat. Selain itu, dalam keadaan kondisi emosi yang tidak stabil atau stress serta pengambilan kafein dianggap berhubungan dengan meningkatnya asam lemak bebas dalam plasma. Hasilnya berlaku peningkatan trigliserida dan kolesterol yang diangkut melalui VLDL dimana hal ini berakibat pada peningkatan kadar kolesterol dalam sirkulasi ${ }^{16}$.

Adapun diet dan gaya hidup adalah faktor yang terlibat dalam merangsang terjadinya peningkatan atau penurunan kadar kolesterol dan hal ini memberi satu pandangan bahwa hiperkolesterolemia merupakan suatu faktor resiko yang bisa dimodifikasi 18. Pada penelitian ini tidak dilakukan food recall dan kajian terhadap aktifitas fisik sampel sebelumnya sehingga kemungkinan penyebab tingginya kadar kolesterol pada sampel yang diperiksa dapat bervariasi. Kemungkinan terbesar adalah akibat konsumsi makanan yang mengandung lemak tinggi dan kurangnya aktifitas fisik disertai faktor hormonal dan kondisi emosional atau tingkat stress yang tinggi dalam menghadapi pekerjaan.

Hasil penelitian yang didapat ini sejalan dengan beberapa penelitian sebelumnya diantaranya penelitian yang dilakukan oleh Nugraha A (2014) yang mendapati bahwa tidak ada hubungan indeks massa tubuh dengan kadar kolesterol total pada guru dan karyawan SMA Muhammadiyah 1 dan 2 Surakarta 19. Harahap (2011) yang meneliti mengenai hubungan kadar kolesterol total dan kadar trigliserida dengan IMT pada pasien di RSUP Hj. Adam Malik Medan yang mendapati bahwa hubungan antara kadar trigliserida dan kadar kolesterol total dengan IMT lemah 20. Penelitian lainnya yang sejalan dengan penelitian ini dilakukan oleh Setiono (2012) dengan menggunakan rancangan penelitian cross sectional. Hasil penelitiannya menyatakan bahwa kadar kolesterol total pada kelompok orang yang obesitas dan tidak obesitas mempunyai perbedaan yang tidak bermakna dengan nilai signifikansi $p=0,457(21)$. Alafanta (2011) melakukan penelitian mengenai pemeriksaan kolesterol pada pasien obesitas yang berusia 30-60 tahun. Hasil penelitian menunjukkan bahwa kadar kolesterol total tinggi tidak selalu berhubungan dengan obesitas.

Hasil penelitian yang berbeda dilakukan oleh Kaleb (2010) pada guru SMK 1 Amurang dengan kesimpulan bahwa terdapat hubungan antara status gizi dengan kadar kolesterol total 23. Hasil penelitian yang tidak sejalan lainnya, dilakukan oleh Mawi (2003) pada sampel orang dewasa yang berusia > 35 tahun. Hasilnya menunjukkan bahwa terdapat hubungan yang bermakna $(p=0,007)$ antara indeks massa tubuh dan kadar kolesterol total yang merupakan indikator penyakit jantung koroner. Kolesterol total pada pria akan semakin meningkat dengan peningkatan nilai IMT. Ini juga didukung oleh hasil studi yang dilakukan di 
Findlandia yang menunjukkan hubungan positif antara kadar kolesterol dengan IMT pada pria dan wanita yang berusia 30-59 tahun ${ }^{14}$.

Adanya perbedaan hasil penelitian ini bisa disebabkan oleh karena perbedaan penggunaan metode penelitian, populasi dan teknik sampel, karakteristik responden (umur, jenis kelamin, dan pekerjaan) serta kriteria kadar kolesterol total dan status gizi yang berbeda. Dalam Penelitian ini digunakan desain penelitian cross sectional, sampelnya adalah pegawai yang bekerja di Poltekkes Kemenkes Medan yang berusia 30-65 tahun dengan pengkategorian obesitas dengan IMT $\geq 30 \mathrm{~kg} / \mathrm{m} 2$, dan non obesitas dengan IMT $<30 \mathrm{~kg} / \mathrm{m}^{2}$ sedangkan kategori obesitas yang digunakan peneliti lain adalah IMT $\geq 25 \mathrm{~kg} / \mathrm{m}^{2}$ bahkan ada yang menggunakan standar obesitas dengan IMT $\geq 23 \mathrm{~kg} / \mathrm{m}^{2}$, dan kriteria kadar kolesterol total pada penelitian lainnya menggunakan kategori normal $(<200 \mathrm{mg} / \mathrm{dL})$, dan kadar kolesterol total tinggi ( $\geq 200 \mathrm{mg} / \mathrm{dL}$ ), pada penelitian ini kami menggunakan kategori dari alat test yang digunakan yaitu autocheck dimana kategori kadar kolesterol normal $\leq 145 \mathrm{mg} / \mathrm{dl}$ dan kadar kolestreol tinggi jika > $145 \mathrm{mg} / \mathrm{dl}$. Hal inilah yang mungkin mempengaruhi sehingga hasil penelitiannya berbeda.

Keterbatasan dari penelitian ini yaitu peneliti tidak mewawancarai responden penelitian secara langsung mengenai kebiasaan makan seperti frekuensi makan dan jenis makanan yang dikonsumsi selama 24 jam terakhir, riwayat merokok, serta aktivitas fisik yang dilakukan responden sebelum ikut dalam penelitian. Akan tetapi, ada beberapa faktor penunjang yang menunjang pelaksanaan penelitian ini yaitu responden yang kooperatif selama penelitian sehingga penelitian ini dapat terlaksana dan juga peneliti dapat memperoleh data-data yang dibutuhkan.

\section{KESIMPULAN}

Kesimpulan yang didapat dari penelitian ini bahwa kadar kolesterol antara pegawai yang obesitas dan non obesitas tidak memiliki perbedaan yang bermakna, dan disarankan bagi pegawai yang memiliki kadar kolesterol tinggi untuk lebih waspada dan melakukan aktifitas yang dapat menurunkan kadar kolesterol seperti olahraga rutin diantaranya olahraga aerobik, bersepeda, atau yoga dan menjaga asupan makanan dengan menghindari makanan yang mengandung lemak jenuh dan lebih banyak mengkonsumsi makanan yang kaya serat dan buah-buahan yang dapat meningkatkan kadar kolesterol HDL seperti alpukat. Diharapkan adanya penelitian lanjutan dengan mengembangkan variabel serta melakukan food recall untuk lebih melengkapi data asupan makanan dan kegiatan fisik.

\section{DAFTAR PUSTAKA}

1. Kamal R, Marcelo LG, et al, Obesityassociated Hypertension: New Insight Into Mechanism, Hypertension ;2005:49:9-14

2. WHO/SEARO. Noncommunicable diseases in the South-East Asia region. Situation and response . India: WHO 2011.

3. Riset Kesehatan Dasar, Riskesdas 2013, Badan Penelitian dan Pengembangan Kesehatan Kemenkes RI Tahun 2013.

4. Riset Kesehatan Dasar, Riskesdas 2010, Badan Penelitian dan Pengembangan Kesehatan Kemenkes RI Tahun 2010.

5. Klein S \& Romijn JA, Obesity in Kronenberg $\mathrm{HM}$ et al, ed. Williams Textbook of Endocrinology 11 th ed, vol. 2, Philadelphia: Saunders an imprint of Elsevier Inc; 2008; p. 1563-1575.

6. Librantoro et al, Correlation between plasma leptin and endothelin-1 plasma level in obese hypertensive subjects, J Kardion Ind ;2007:28:246-255. 
7. Almatsier S, Prinsip Dasar Ilmu Gizi. Jakarta : Gramedia Pustaka Utama:2009.

8. Direktorat Kesehatan dan Gizi Masyarakat:Laporan pembangunan kesehatan dalam RPJMN 2010-2014, Badan perencanaan pembangunan nasional: 2009.

9. Ibrahim MM, Subcutaneous and visceral adipose tissue: structural and functional differences, Journal compilation (c) International Association for the Study of Obesity. obesity reviews 11: 2009:1118.

10. The Asia-Pacific perspective: Redefining obesity and its treatment, WHO Western Pacific Region, Health Communications Australia, February 2000

11. Bravo PE et al, Leptin and hypertension in obesity, Vaskuler health and risk management: 2006:2(2):163-169

12. Shah SZA, Devrajani BR, Devrajani $T$, Bibi I. Frequency of Dyslipidemia in Obese versus Nonobese in relation to Body Mass Index (BMI), Waist Hip Ratio (WHR) and Waist Circumference (WC). Pakistan Journal of Science:2008: 62 (1): 27-31.

13. World Health Organisation (WHO). Obesity and Overweight. http://www.who.int/mediacentre/fact sheets/fs311/en/index.html diakses pada 28 agustus 2013

14. Mawi M, Indeks Massa Tubuh Sebagai Determinan Penyakit Jantung Koroner Pada Orang Dewasa Berusia Di Atas 35 Tahun. Jurnal Kedokteran Trisakti :2003:Vol XXIII No.3.
15. Dewi R dkk, Hubungan Kadar Kolesterol, IMT, Lingkar Pinggang Dengan Derajat Premenstrual Syndrome PadaWanita Usia Subur, Program Pasca Sarjana FK UNHAS; 2010, Makassar

16. Botham, K.M. \& Mayes, P.A. Murray, R. K., Granner, D. K., \& Rodwell,V. M., Chapter 26, Cholesterol Synthesis,Transport and excretion.. In:Harper's Illustrated Biochemistry 27th ed. USA: McGraw-Hill ;2006;230240

17. Guyton, A.C.\& Hall, J.E. Lipid Metabolism. In : Textbook of Medical physiology 11th ed. USA: Saunders Elsevier ; 2006: 840-851

18. Kumar, V., Abbas, K. A., Fausto, N., \& Mitchell, R. N., 2007. Chapter 10, The Blood Vessel. In : Robbins Basic Pathology 8th ed. USA : Saunders Elsevier ;2007; 347-349

19. Nugraha A, Hubungan Indeks Massa Tubuh Dengan Kadar Kolesterol Total Pada Guru Dan Karyawan SMA MUHAMMADIYAH 1 Dan 2 Surakarta, Fakultas Kedokteran Universitas Muhammadiyah Surakarta ; Skripsi;2014

20. Harahap T, Hubungan Antara Kadar Kolesterol Total Dan Kadar Trigliserida Dengan Indeks Massa Tubuh Pada Pasien Di Instalasi Patologi Klinik Rsup H. Adam Malik Medan. Karya Tulis Ilmiah; 2011. 
